\title{
Knowledge and Attitude Towards Second COVID-19 Vaccine Dose Among Health Professionals Working at Public Health Facilities in a Low Income Country
}

\author{
Mohammedjud Hassen Ahmed (D) ' \\ Shuayib Shemsu Siraj ${ }^{2}$ \\ Jorn Klein (iD ${ }^{3}$ \\ Fedila Yassin $\mathrm{Ali}^{4}$ \\ Shuma Gosha Kanfe (D) ' \\ 'Department of Health Informatics, \\ College of Health Sciences, Mettu \\ University, Mettu, Ethiopia; ${ }^{2}$ Department \\ of Public Health, College of Medicine and \\ Health Sciences, Mettu University, Mettu, \\ Ethiopia; ${ }^{3}$ University of South-Eastern \\ Norway, Porsgrunn, Norway; \\ ${ }^{4}$ Department of Public Health, College of \\ Health Sciences, Wolkite University, \\ Wolkite, Ethiopia
}

Background: Several vaccines have been approved in a lot of countries to combat coronavirus disease and distributed throughout the world. Health professional's knowledge and attitude towards a second COVID-19 vaccine dose were poorly implemented and understood in Ethiopia's health facilities. The main purpose of conducting this study was to investigate health professionals' knowledge and attitude towards the second COVID-19 vaccine dose at public hospitals in Ethiopia.

Methods: A cross-sectional study design was conducted from January to March, 2021 to assess the knowledge and attitude towards second COVID-19 vaccine dose among health professionals working at public health facilities in Ethiopia. A multivariable logistic regression was performed to identify predictors that correlate with knowledge and attitude towards a second COVID-19 vaccine dose with a $P$-value $<0.05$ as a cut-off point for statistical significance at $95 \%$ confidence interval (CI).

Results: Four hundred and nine study subjects participated, with a response rate of $96.7 \%$. In this study, more than half of the respondents had high knowledge towards second COVID19 vaccine doses. Similarly, $95.6 \%$ of respondents had a favorable attitude towards second COVID-19 vaccine doses. Educational status (AOR=1.82, 95\% CI=1.1-2.2), age $(\mathrm{AOR}=2.01,95 \% \mathrm{CI}=1.76-3.01)$, and profession $(\mathrm{AOR}=2.32,95 \% \mathrm{CI}=1.42-3.01)$ were variables associated with knowledge towards second COVID-19 vaccine doses. Educational status $(\mathrm{AOR}=5.42,95 \% \mathrm{CI}=4.1-6.7)$, age $(\mathrm{AOR}=12.4,95 \% \mathrm{CI}=10.54-15.8)$, professionals $(\mathrm{AOR}=4.33,95 \% \mathrm{CI}=2.32-6.87)$, working experience $(\mathrm{AOR}=4.33,95 \%$ $\mathrm{CI}=2.32-6.87)$, marital status $(\mathrm{AOR}=2.47,95 \% \mathrm{CI}=1.33-5.95)$, risk degree $(\mathrm{AOR}=2.33$, $95 \% \mathrm{CI}=1.31-4.11)$ and gender $(\mathrm{AOR}=3.42,95 \% \mathrm{CI}=2.91-4.98)$ were determinant factors of attitude towards the second COVID-19 vaccine dose.

Conclusion: Addressing problems related with risk degree, educational status, and sociodemographic factors will help to increase the overall knowledge and attitude towards second COVID-19 vaccine doses.

Keywords: COVID-19, health professionals, attitude, second vaccine dose, knowledge, Ethiopia

\section{Background}

Correspondence: Mohammedjud Hassen Ahmed

Department of Health Informatics, Mettu University, College of Health Sciences,

Mettu, Ethiopia

Tel +251 920188972

Email judhassen423@gmail.com
The current COVID-19 pandemic facing the world in danger of all aspects. ${ }^{1-3} \mathrm{~A}$ retrospective investigation was conducted by the Chinese to identify the symptoms and onsets of the virus during early December 2019 to confirm SARS Cov-2 as the cause of COVID-19. The virus SARS-CoV-2 (abbreviation for severe acute respiratory syndrome coronavirus type 2 ), known as a (novel) coronavirus, is a pathogen 
similar to the SARS coronavirus that emerged in 2002. Both Novel coronal virus and SARS corona virus belong to the beta-coronavirus group and are of probably zoonotic origin. ${ }^{4}$ The virus was confirmed as the cause of the COVID-19 disease in early $2020 .{ }^{5}$

In Ethiopia, the COVID-19 situation has become a major issue and the government has been taking several measures to tackle the spread of the disease. ${ }^{6}$ Nevertheless, the COVID-19 pandemic is getting more difficult to control and reduce the transmission rate throughout the world. ${ }^{7-12}$ Even though a lot of effort has been made globally to develop vaccines against COVID19 , the loss of trust towards the effect of vaccination led to a low coverage of vaccination throughout the world. ${ }^{7,13}$ This has resulted in reduced productivity, increased absenteeism, and dangerous outbreaks of the virus. ${ }^{6}$

Several studies have identified that knowledge and attitude determine the acceptance of vaccine against COVID-19. ${ }^{6,7,14}$ A study revealed that the importance of conducting research on knowledge and attitude towards vaccination has become a hot topic right now in Ethiopia to reduce the transmission rate of the disease. ${ }^{15}$ The knowledge about vaccines against COVID-19 was affected by the factors asymptomatic with COVID-19, household income, high-risk of COVID-19, age, belief about vaccine, education level, and religion. ${ }^{16,17}$ The factors vaccine history, perceived impact of COVID-19, understanding of vaccine immunity, political ideology, household income, and information about the vaccine were identified as the factors associated with attitude toward vaccination against COVID-19.,18 It is identified that a lot of respondents responded "yes" when asked about COVID-19 vaccine, whereas only $80(4.58 \%)$ of respondents said that they did not know about vaccinations against COVID-19. ${ }^{19}$

In a study conducted in west India, knowledge, attitude, and practice (KAP) of the local population towards the COVID-19 vaccine was critical to understand the epidemiological dynamics of disease control, and the effectiveness, compliance, and success of the vaccination program ${ }^{17}$ However, lack of knowledge about vaccine remained a reason in hindering vaccination where more than half of the respondents (56.4\%) still had no knowledge about the presence of vaccines against COVID-19. ${ }^{20}$ Another study has shown that the majority $(81.5 \%)$ of the respondents believed that it was important to get vaccinated to protect the community from COVID-19. ${ }^{21}$ This is directly related to the presence of high knowledge about vaccines against COVID-19. A study conducted on attitude towards vaccine against COVID-19 also revealed that timing, efficacy, and location will determine the attitude. ${ }^{19}$ However, around $70 \%$ of participants indicated that they had a positive attitude towards vaccines against COVID-19. ${ }^{4}$

A study conducted on the vaccine supported that the side-effects of the vaccine will determine and directly associate with attitude, where over $80 \%$ of respondents stated that vaccines could have an adverse effect on participants health. ${ }^{15}$ Knowledge about health issues is a central component of health literacy and is considered a prerequisite for health decision-making process. ${ }^{20,21}$ The lack of scientifically accurate knowledge influenced negative attitude towards vaccine. ${ }^{37-40}$ Vaccine knowledge was one of the strongest factors associated with vaccination intention to receive COVID-19 vaccine in China. ${ }^{41,42}$

In order to achieve an effective and efficient vaccination outcome against COVID-19, building trust and increasing awareness among health professionals is an important step to receive COVID-19 vaccine to prevent transmission of the COVID-19 pandemic. ${ }^{13}$

As the Ethiopian federal ministry of health has tried to implement a vaccination strategy, it's a mandatory step to know the knowledge and attitude of health professionals about the second COVID-19 vaccine doses. In addition to this, there has been no prior study among health professionals in our areas investigating their knowledge and attitude towards second COVID-19 vaccine doses. Generally, the study question is to examine the knowledge and attitude of health care providers towards second COVID-19 vaccine doses.

\section{Methods}

\section{Study Design, Area, and Period}

A cross-sectional study design was conducted from January to March 2021 at Karl referral hospital, Darimu hospital, Dembi hospital, Chora hospital and Bedelle hospital, south west Ethiopia.

\section{Study Subjects and Participants}

All health professionals working at all public hospitals of Ilu aba bore and Bedelle zones were included in the study. Health professionals who have less than 6 months working experience were excluded from the study.

\section{Sample Size Determination and Sampling Procedure}

A single population proportion formula $\left(\mathrm{n}=\left[(\mathrm{Z} \alpha / 2)^{2} \mathrm{P}(1-\right.\right.$ $\mathrm{P})] / \mathrm{d}^{2}$ ) was determined to calculate the total sample size. 
Fifty per cent $(50 \%)$ was used to calculate the sample size due to no previous research being done on knowledge and attitude towards second COVID-19 vaccine dose. By considering the $95 \%$ confidence interval $(Z \alpha / 2=1.96)$, a marginal of error (d) of $5 \%$ and $10 \%$ non-response, a sample size of 423 was used. Karl referral hospital, Darimu hospital, Dembi hospital, Chora hospital, and Bedelle hospital located within the two zones were selected for the study. There were a total of 851 health professionals in these study settings. A total sample size of 423 participants were proportionally allocated for each selected hospital. The participants were selected from each hospital using simple random sampling technique.

The data were collected using a self-administered questionnaire. The questionnaire was prepared in English. Seven data collectors, who have good experience in data collection, were recruited for data collection.

\section{Data Quality Control}

The questionnaire was pretested on 25 study participants who were working at Jimma referral hospital. Based on the pretest, necessary modifications of the questionnaire were done. The content validity of the questionnaire was checked, and the reliability was calculated using Cronbach alpha's coefficient (overall Cronbach $\alpha=0.87$ ). A total of three degree holder health professionals as supervisors and nine health professionals as data collectors participated in the data collection process after 2 days of training. During data collection process, the study participants were informed about the study and confidentiality of the information. Multi-collinearity was tested by running a false linear regression and the study result showed that the entire variance inflation factor (VIF) value was less than 2 and the tolerance was greater than 0.78 which confirmed the absence of multi-collinearity. The data was checked by box plot for outliers and there was no outlier observed in the study. The goodness of fit of the model was checked.

\section{Data Processing and Analysis}

The questionnaires were entered into software Epi info version 7 and SPSS version 20 was used for data analysis. Binary logistic regression analysis was used to identify factors associated with knowledge and attitude towards the second COVID-19 vaccine dose. Bivariable and multivariable logistic regression were conducted to describe the association between each factor with dependent variables. $P$-values $<0.2$ and $<0.05$ were significance test cut-off values for bivariable and multivariable analysis, respectively. Variables having a $P$-value $<0.2$ on the bivariate analysis were entered into a multivariable logistic regression analysis to check for confounding effects on the association from bivariable analysis. The strength of association was described at $95 \% \mathrm{CI}$, and a $P$-value less than 0.05 was considered for multivariable logistic regression analysis. A multi-collinearity test was conducted for the model and none of the variables were scored above 10 for the test statistics.

\section{Results}

\section{Socio Demographic Characteristics of the Participants}

Four hundred and nine participants were enrolled in the study. The mean age of the participants was 32.7 with a standard deviation of \pm 11.8 . Two hundred and sixty $(63.6 \%)$ of the participants were married. Two hundred and sixty-three $(64.3 \%)$ of the study participants had a degree, and $44(10.8 \%)$ of them were masters and above masters. Two hundred and fifty-three (61.9\%) of the study participants had an income of 5,000 and only $27(6.6 \%)$ of the participants earned 10,000-15,000 (Table 1).

\section{Participant's Health Status}

One hundred and one (24.7\%) of the respondents had chronic disease. Ninety percent of the respondents were at high risk of COVID-19 complications, and 9.0\% were at medium risk, as shown in Table 2.

\section{Participant's Knowledge Towards Second COVID-19 Vaccine Dose}

This study revealed that $298(72.9 \%)$ of the participants perceived that the second COVID-19 vaccine dose increases allergic reaction. Knowledge about the second COVID-19 vaccine dose was $64.00 \%$. Three hundred and eighty-four $(93.9 \%)$ respondents declared that they know about the second COVID-19 vaccine dose, as shown in Table 3 .

\section{Participants' Attitude Towards Second COVID- 19 Vaccine Dose}

About half of the participants $(209 ; 51.1 \%)$ reported that the newly discovered second COVID-19 vaccine dose is safe. Around $201(49.7 \%)$ of participants declared that it is not possible to reduce the prevalence of COVID-19 without a second vaccine dose. Three hundred and eighty-six 
Table I Health Care Provider's Socio-Demographic Characteristics of Knowledge and Attitude Towards Second Dose COVID-19 Vaccine

\begin{tabular}{|c|c|c|}
\hline Variables & Category & Frequency \% $(n=409)$ \\
\hline \multirow[t]{2}{*}{ Sex } & Male & $287(70.2)$ \\
\hline & Female & $122(29.8)$ \\
\hline \multirow[t]{5}{*}{ Age } & $20-29$ & $103(25.2)$ \\
\hline & $30-39$ & $221(54.0)$ \\
\hline & $40-49$ & $37(9.0)$ \\
\hline & $50-59$ & $33(8.1)$ \\
\hline & $>59$ & $15(3.7)$ \\
\hline \multirow[t]{2}{*}{ Marital status } & Not married & $|3|(32.0)$ \\
\hline & Married & $278(68.0)$ \\
\hline \multirow[t]{12}{*}{ Profession } & Nurse & 163 (39.9) \\
\hline & Psychiatry & $7(1.7)$ \\
\hline & Optometry & $6(1.5)$ \\
\hline & Midwifery & $68(16.6)$ \\
\hline & Physician & $105(25.7)$ \\
\hline & Health officer & $6(1.5)$ \\
\hline & Anesthetics & $7(1.7)$ \\
\hline & Laboratory & $9(2.2)$ \\
\hline & Radiology & $8(1.9)$ \\
\hline & Physiotherapy & $7(1.7)$ \\
\hline & Pharmacist & $17(4.1)$ \\
\hline & Other & $6(1.5)$ \\
\hline \multirow[t]{3}{*}{ Educational status } & Diploma & $102(24.9)$ \\
\hline & Degree & $263(64.3)$ \\
\hline & MSc and above & $44(10.8)$ \\
\hline \multirow[t]{3}{*}{ Monthly Income } & $<5,000$ & $253(6 I .9)$ \\
\hline & $5,000-10,000$ & $129(31.5)$ \\
\hline & $10,000-15,000$ & $27(6.6)$ \\
\hline \multirow[t]{4}{*}{ Working experience } & $1-3$ & $89(21.8)$ \\
\hline & $3-5$ & $123(30.1)$ \\
\hline & $5-10$ & $179(43.7)$ \\
\hline & $>10$ & $18(4.4)$ \\
\hline
\end{tabular}

Table 2 Respondents Health Status

\begin{tabular}{|c|c|c|}
\hline Variables & Category & $\begin{array}{l}\text { Frequency } \\
\%(n=409)\end{array}$ \\
\hline Do you have any chronic diseases? & $\begin{array}{l}\text { Yes } \\
\text { No }\end{array}$ & $\begin{array}{l}101(24.7) \\
308(75.3)\end{array}$ \\
\hline Risk degree & $\begin{array}{l}\text { High Risk } \\
\text { Medium } \\
\text { Risk } \\
\text { Low Risk }\end{array}$ & $\begin{array}{l}365(89.2) \\
36(8.8) \\
8(2.0)\end{array}$ \\
\hline $\begin{array}{l}\text { Have you received all the necessary } \\
\text { vaccination in your lifetime? }\end{array}$ & $\begin{array}{l}\text { Yes } \\
\text { No }\end{array}$ & $\begin{array}{l}263(64.3) \\
146(35.7)\end{array}$ \\
\hline
\end{tabular}

Table 3 Participants' Knowledge About Second COVID-19 Vaccine Doses

\begin{tabular}{|c|c|c|}
\hline Variables & Category & $\begin{array}{l}\text { Frequency } \\
\%(n=409)\end{array}$ \\
\hline \multicolumn{3}{|c|}{ Knowledge about Second Dose COVID-19 vaccines? } \\
\hline $\begin{array}{l}\text { Do you know about second COVID-19 } \\
\text { vaccine dose? }\end{array}$ & $\begin{array}{l}\text { Yes } \\
\text { No }\end{array}$ & $\begin{array}{l}384(93.9) \\
25(17.6 .8)\end{array}$ \\
\hline $\begin{array}{l}\text { Do you know about the effectiveness } \\
\text { of second COVID-19 vaccine dose? }\end{array}$ & $\begin{array}{l}\text { Yes } \\
\text { No }\end{array}$ & $\begin{array}{l}304(74.3) \\
105(25.7)\end{array}$ \\
\hline $\begin{array}{l}\text { Is it very dangerous for health using } \\
\text { second vaccine overdoses? }\end{array}$ & $\begin{array}{l}\text { Yes } \\
\text { No }\end{array}$ & $\begin{array}{l}301(73.4) \\
108(26.6)\end{array}$ \\
\hline $\begin{array}{l}\text { Does second vaccine dose increase } \\
\text { allergic reactions? }\end{array}$ & $\begin{array}{l}\text { Yes } \\
\text { No }\end{array}$ & $\begin{array}{l}298(72.9) \\
111(27.1)\end{array}$ \\
\hline $\begin{array}{l}\text { Does second vaccine dose increase } \\
\text { autoimmune diseases? }\end{array}$ & $\begin{array}{l}\text { Yes } \\
\text { No }\end{array}$ & $\begin{array}{l}357(87.3) \\
52(12.7)\end{array}$ \\
\hline
\end{tabular}

(94.4\%) participants stated that they will encourage their families and friends to get vaccinated again (Table 4).

\section{Binary Logistic Regression Analysis of Knowledge Towards the Second COVID- 19 Vaccine Dose}

A total of nine variables were entered into the binary logistic regression model. From the total, gender, educational status, profession, monthly income, marital status, age, working experience, and chronic disease status were significantly associated with knowledge towards the second COVID-19 vaccine dose in bivariable analysis. Among nine variables, educational status, age, and profession were the only factors significantly associated with knowledge in the multivariable logistic regression analysis. Professionals who are MSc and above MSc had 2times (AOR=1.82, 95\% CI=1.1-2.2) higher knowledge towards the second COVID-19 vaccine dose as compared to professionals with Diploma. Regarding age, the odds of knowledge were $2(\mathrm{AOR}=2.01,95 \% \mathrm{CI}=1.76-3.01)$ times higher among professionals with age of 30-39 level as compared to professionals who are 20-29 (Table 5).

\section{Binary Logistic Regression Analysis of Attitude Towards Second COVID-19 Vaccine Dose}

A total of nine variables were entered into a bivariable logistic regression model. From the total, Gender, Profession, Educational status, Monthly income, marital 
Table 4 Participants' Attitude About Second COVID-19 Vaccine Dose

\begin{tabular}{|l|l|l|}
\hline Variables & Category & $\begin{array}{l}\text { Frequency } \\
\%(\mathbf{n}=409)\end{array}$ \\
\hline \multicolumn{2}{|l|}{ Attitude towards second dose COVID-19 vaccine } \\
\hline $\begin{array}{l}\text { The newly discovered second COVID- } \\
\text { I9 vaccine dose is safe }\end{array}$ & $\begin{array}{l}\text { Yes } \\
\text { No }\end{array}$ & $\begin{array}{l}209(5 I .1) \\
200(48.9)\end{array}$ \\
\hline $\begin{array}{l}\text { The second COVID-19 vaccine dose is } \\
\text { essential for Ethiopia }\end{array}$ & $\begin{array}{l}\text { Yes } \\
\text { No }\end{array}$ & $\begin{array}{l}243(59.4) \\
166(40.6)\end{array}$ \\
\hline $\begin{array}{l}\text { I will encourage my family, friends and } \\
\text { relatives to get vaccinated against } \\
\text { COVID-19 again }\end{array}$ & Yes & $\begin{array}{l}386(94.4) \\
23(5.6)\end{array}$ \\
\hline $\begin{array}{l}\text { I will take second COVID-19 vaccine } \\
\text { dose without any hesitation, if it is } \\
\text { available in Ethiopia }\end{array}$ & Yes & $\begin{array}{l}341(83.4) \\
66(16.6)\end{array}$ \\
\hline $\begin{array}{l}\text { It is not possible to reduce the } \\
\text { prevalence of COVID-19 without a } \\
\text { second vaccine dose }\end{array}$ & Nos & $\begin{array}{l}201(49.1) \\
208(50.9)\end{array}$ \\
\hline $\begin{array}{l}\text { The second COVID-I9 vaccine doses } \\
\text { should be distributed fairly to all of us }\end{array}$ & Yes & $\begin{array}{l}103(25.2) \\
306(74.8)\end{array}$ \\
\hline
\end{tabular}

status, Age, Working experience, and Risk degree status were factors associated with bivariable logistic regression at a $P$-value of less than 0.2 and entered into multivariable binary logistic regression analysis. From nine variables, only educational status, age, marital status, risk degree, and profession were found to be significantly associated with attitude in the multivariable logistic regression analysis. With respect to educational status, professionals who are MSc and above MSc had 5-times (AOR $=5.42,95 \%$ $\mathrm{CI}=4.1-6.7)$ higher attitude towards second COVID-19 vaccine dose as compared to professionals with Diploma. Regarding Age, the odds of attitude were $2(\mathrm{AOR}=0.2$, 95\% CI $=1.84-3.26)$ times higher among professionals with age of $>59$ as compared to professionals who are 20-29. Professionals who have working experience of $>10$ years had 4-times $(\mathrm{AOR}=4.33,95 \% \mathrm{CI}=2.32-6.87)$ higher attitude towards COVID-19 as compared to professionals with $<3$ years (Table 6).

\section{Discussion}

The study was conducted among health care providers collected from public hospitals in Ethiopia to assess the knowledge and attitude towards second COVID-19 vaccine dose to achieve efficient and effective vaccination policy in Ethiopia. It is essential to determine and focus the healthcare providers' knowledge and attitude to combat the rate of transmission as they are frontline workers and the exposed group of this COVID-19 pandemic. $^{38,43,44}$ Thus, educational status, ages, and professionwere factors statistically correlated with knowledge towards second COVID-19 vaccine dose. Marital status, age, gender, educational status, working experience, risk degree, and profession were associated factors that determined the attitude of health care providers towards second vaccine doses against COVID-19.

The magnitudes of knowledge about vaccine were assessed and $64.0 \%(95 \% \mathrm{CI}=58.62-67.89 \%)$ of study participants had good knowledge about the second vaccine dose against COVID-19. This result was inconsistent with a study conducted in west India where $58.0 \%$ of the study subjects rejected the presence of a vaccine against COVID-19. ${ }^{17}$ Time variation might be the possible explanations for these variations. However, this result was lower than a study conducted in Greece, where the majority of subjects $(88.3 \%)$ had a good level of knowledge about second vaccine doses against COVID-19. ${ }^{45}$ A study conducted in Romania was also greater than the result of this study, where only $4.85 \%$ of study participant said that they did not know the benefits of the second COVID-19 vaccine dose. ${ }^{15}$ Similarly, a study shows that the majority $(81.5 \%)$ of the respondents agreed that it is important to take a second vaccine dose to protect people from COVID-19, which was greater than the result of this study. ${ }^{21}$ Possible explanations for this variation might be due to the prevalence of the COVID-19 pandemic, source of information, and vaccination policy. Similarly, sources of information also matters because more than half of Ethiopians are living in rural areas.

Educational status was significantly associated with knowledge about the second vaccine dose against COVID-19. The odds of a study subject with MSc and above educational status were about 2-times $(\mathrm{AOR}=1.82$, 95\% CI $=1.1-2.2$ ) more likely to have higher knowledge about second vaccination dose against COVID-19 as compared to subjects with diploma holders. This result was similar to a study conducted in west India and Bangladesh that study subjects with a higher level of educational status were more likely to have higher knowledge about the second vaccine dose against COVID-19. ${ }^{17,21}$ Accordingly, the odds of knowledge were $2(\mathrm{AOR}=2.01$, 95\% CI $=1.76-3.01$ ) times higher among professionals aged 30-39 as compared to professionals who are 20-29. Similarly, a studies conducted in west India and 
Table 5 Binary Logistic Regression Analysis of Knowledge Towards Second COVID-19 Vaccine Dose

\begin{tabular}{|c|c|c|c|c|}
\hline \multirow[t]{2}{*}{ Variables } & \multicolumn{2}{|c|}{ Knowledge } & \multirow[t]{2}{*}{ COR $(95 \% \mathrm{Cl})$} & \multirow[t]{2}{*}{ AOR (95\% Cl) } \\
\hline & Yes & No & & \\
\hline \multicolumn{5}{|l|}{ Gender } \\
\hline Male & 200 & 87 & $0.45(0.39-0.57)$ & $0.31(0.21-1.55)$ \\
\hline Female & 102 & 20 & I & I \\
\hline \multicolumn{5}{|l|}{ Profession } \\
\hline Nurse & 101 & 62 & $0.33(0.12-0.42)$ & $0.27(0.19-1.98)$ \\
\hline Psychiatry & 5 & 2 & $0.52(0.36-0.62)$ & $0.42(0.3 \mathrm{I}-2.0 \mathrm{I})$ \\
\hline Optometry & 4 & 2 & $0.4 \mathrm{I}(0.32-0.53)$ & $0.37(0.26-2.21)$ \\
\hline Midwifery & 59 & 9 & $1.34(1.85-2.31)$ & $0.87(0.72-2.13)$ \\
\hline Physician & 98 & 7 & $2.87(1.23-, 3.91)$ & $2.32(1.42-3.01)^{* *}$ \\
\hline Health officer & 5 & 1 & $1.03(1.01-2.32)$ & $0.75(0.70-1.25)$ \\
\hline Anesthesia & 5 & 2 & $0.5 \mathrm{I}(0.46-0.61)$ & $0.47(0.37-1.99)$ \\
\hline Other & 39 & 8 & 1 & 1 \\
\hline \multicolumn{5}{|l|}{ Marital status } \\
\hline Married & 191 & 86 & $0.63(0.56-, 0.78)$ & $0.57(0.53-1.56)$ \\
\hline Not Married & 102 & 29 & 1 & 1 \\
\hline \multicolumn{5}{|c|}{ Educational Status } \\
\hline Diploma & 79 & 23 & 1 & I \\
\hline Degree & 192 & 71 & $0.79(0.66-0.95)$ & $0.59(0.44-1.23)$ \\
\hline MSc and Above & 38 & 6 & $1.84(1.13-2.43)$ & $1.82(1.1-2.2)^{* *}$ \\
\hline \multicolumn{5}{|l|}{ Monthly income } \\
\hline$>5,000$ & 200 & 53 & 1 & 1 \\
\hline 10,000 & 89 & 40 & $0.59(0.5 \mathrm{I}-0.78)$ & $0.54(0.5|-2.3|)$ \\
\hline $10,000-15,000$ & 19 & 8 & $0.63(0.44-1.95)$ & \\
\hline \multicolumn{5}{|l|}{ Age } \\
\hline $20-29$ & 79 & 24 & 1 & 1 \\
\hline $30-39$ & $|8|$ & 40 & $1.37(1.21-2.55)$ & $2.0 \mathrm{I}(\mathrm{I} .76-3.0 \mathrm{I})^{* *}$ \\
\hline $40-49$ & 29 & 8 & $1.10(0.85-1.74)$ & \\
\hline $50-59$ & 23 & 10 & $0.70(0.45-0.91)$ & $0.67(0.57-2.01)$ \\
\hline$>59$ & 9 & 6 & $0.46(0.33-0.56)$ & $0.41(0.31-1.53)$ \\
\hline \multicolumn{5}{|c|}{ Working experience } \\
\hline I-3 years & 69 & 20 & I & I \\
\hline $3-5$ years & 83 & 40 & $0.60(0.44-2.12)$ & \\
\hline $5-10$ years & 129 & 50 & $0.75(0.55-0.88)$ & $0.43(0.34-1.67)$ \\
\hline$>10$ years & 10 & 8 & $0.36(0.24-0.58)$ & $0.29(0.24-1.38)$ \\
\hline \multicolumn{5}{|c|}{ Have chronic disease(s) } \\
\hline Yes & 90 & 56 & $0.52(0.4 \mathrm{I}-0.65)$ & $0.48(0.39-0.61)$ \\
\hline No & 199 & 64 & 1 & I \\
\hline
\end{tabular}

Notes: **Significant at $P<0.01$, 'Reference category.

Bangladesh were consistent with the results of this study. $^{17,21}$

Physicians were about 2-times $(\mathrm{AOR}=2.32,95 \%$ $\mathrm{CI}=1.42-3.01)$ more likely to have higher knowledge about second vaccination against COVID-19 as compared to subjects not being a physician. The result of this study was consistent with studies conducted in Greece and the Democratic Republic of the Congo. ${ }^{43,45}$ The attitude of healthcare providers in this study was also assessed where $87.1 \%$ of respondents have a favorable attitude towards second vaccine dose against COVID-19. Healthcare providers' attitude towards the second vaccination dose 
Table 6 Binary Logistic Regression Analysis of Attitude Towards COVID-19 Second Vaccine Doses

\begin{tabular}{|c|c|c|c|c|}
\hline \multirow[t]{2}{*}{ Variables } & \multicolumn{2}{|c|}{ Knowledge } & \multirow[t]{2}{*}{ COR $(95 \% \mathrm{CI})$} & \multirow[t]{2}{*}{ AOR (95\% Cl) } \\
\hline & Yes & No & & \\
\hline \multicolumn{5}{|l|}{ Gender } \\
\hline Male & 196 & 91 & $4.4 I(3.2 I-5.67)$ & $3.42(2.91-4.98)^{* *}$ \\
\hline Female & 40 & 82 & 1 & I \\
\hline \multicolumn{5}{|l|}{ Profession } \\
\hline Nurse & 91 & 72 & $0.78(0.61-0.99)$ & $0.54(0.48-1.63)$ \\
\hline Psychiatry & 4 & 3 & $0.83(0.66-0.92)$ & $0.48(0.35-1.91)$ \\
\hline Optometry & 3 & 3 & $0.62(0.4 I-0.78)$ & 0.55 (0.5I-I.II) \\
\hline Midwifery & 40 & 28 & $0.88(0.8 \mathrm{I}-0.97)$ & $0.83(0.77-1.24)$ \\
\hline Physician & 86 & 19 & $2.80(\mid .23-3.91)$ & $2.42(1.55-4.43)^{* *}$ \\
\hline Health officer & 2 & 4 & $0.31(0.19-1.32)$ & \\
\hline Anesthesia & 4 & 3 & $0.3 I(0.2 I-0.4 I)$ & $0.24(0.18-1.88)$ \\
\hline Other & 29 & 18 & 1 & 1 \\
\hline \multicolumn{5}{|l|}{ Marital status } \\
\hline Married & 214 & 63 & $2.83(1.46-3.56)$ & $2.47(1.33-, 5.95)^{* *}$ \\
\hline Not Married & 72 & 60 & 1 & 1 \\
\hline \multicolumn{5}{|c|}{ Educational Status } \\
\hline Diploma & 70 & 32 & 1 & 1 \\
\hline Degree & 189 & 74 & $0.79(0.66-0.95)$ & $0.59(0.44-1.23)$ \\
\hline MSc and Above & 41 & 3 & $6.2(4.56-8.55)$ & $5.43(4.1-6.7)^{* * *}$ \\
\hline \multicolumn{5}{|l|}{ Monthly income } \\
\hline$>5,000$ & 98 & 155 & 1 & 1 \\
\hline 10,000 & 89 & 40 & $0.59(0.5 I-0.78)$ & $0.54(0.5 \mid-2.3 I)$ \\
\hline $10,000-15,000$ & 23 & 4 & $0.63(0.55-1.95)$ & \\
\hline \multicolumn{5}{|l|}{ Age } \\
\hline $20-29$ & 51 & 52 & 1 & I \\
\hline $30-39$ & 179 & 42 & $4.3(2.98-5.54)$ & $3.72(2.13-4.52)^{* *}$ \\
\hline $40-49$ & 27 & 10 & $0.78(0.74-1.54)$ & \\
\hline $50-59$ & 19 & 14 & $1.38(1.21-1.87)$ & $1.21(0.43-1.75)$ \\
\hline$>59$ & 10 & 4 & $2.54(1.96-3.87)$ & $2.2(1.84-3.26)^{* * *}$ \\
\hline \multicolumn{5}{|c|}{ Working experience } \\
\hline I-3 years & 48 & 41 & 1 & I \\
\hline $3-5$ years & 63 & 60 & $0.60(0.44-2.12)$ & \\
\hline $5-10$ years & 109 & 70 & $1.33(0.79-1.99)$ & \\
\hline$>10$ years & 16 & 2 & $6.83(5.33-7.98)$ & $4.33(2.32-6.87)^{* * *}$ \\
\hline \multicolumn{5}{|l|}{ Risk degree } \\
\hline High Risk & 300 & 65 & $1.54(1.24-3.43)$ & $2.33(I .3 I-4.1 I)^{* *}$ \\
\hline Medium Risk & 30 & 6 & $\mathrm{I} .67(\mathrm{I} .2 \mathrm{I}-5.28)$ & $1.37(0.98-3.66)$ \\
\hline Low Risk & 6 & 2 & 1 & I \\
\hline
\end{tabular}

Notes: **Significant at $P<0.01$, ***Significant at $P<0.001$. 'Reference category.

against COVID-19 was high. Studies conducted in Belgium and Canada (79.6\%), the USA (68\%), the UK $(38 \%)$, and Italy $(75 \%)$ were among those conducted studies with results lower than this study. ${ }^{4,46-48}$ This might be due to the fact that COVID-19 prevalence was getting worse than ever in Ethiopia. ${ }^{12,49}$

Educational status was found to be a significant factor for attitude towards second vaccine dose against COVID-19. 
Thus, professionals who are MSc and above MSc had 5times $(\mathrm{AOR}=5.42,95 \% \mathrm{CI}=4.1-6.7)$ higher attitude towards the second COVID-19 vaccine dose as compared to professionals with a Diploma. Studies conducted in the UK and Italy were consistent with the result of this study. ${ }^{48,50}$ However, the result of this study was inconsistent with studies conducted in Bangladesh and Romania. ${ }^{15,21}$ A possible explanation for this variation might be that in Ethiopia respondents with a higher education status were more likely to get information about vaccines, whereas those with a diploma and the like are most likely living in rural areas. However, advancement of technology that encourages information about vaccines against COVID-19 in the two countries might be the reason for the differences.

Another significant factor was age, where the odds of attitude were $2(\mathrm{AOR}=2.2,95 \% \mathrm{CI}=1.84-3.26)$ times higher among professionals aged $>59$ as compared to professionals who are 20-29. This result was inconsistent with another study conducted in the UK where young people were significantly less likely than older adults to have a negative attitude towards the second COVID-19 vaccine dose, ${ }^{50}$ but similar to studies conducted in Belgium and Canada. ${ }^{46}$ The study is inconsistent with a study conducted in Italy, which revealed that age has no significant association with attitude towards the second vaccine dose against COVID-19. ${ }^{48}$ This might be due to the fact that there is an opinion that older people could be more exposed to COVID-19 than those who are young.

Health care providers who have long periods of working experience were more likely to have a favorable attitude towards the second COVID-19 dose. Thus, professionals who have working experience of $>10$ years had a 4-times $(\mathrm{AOR}=4.33,95 \% \mathrm{CI}=2.32-6.87)$ higher attitude towards the second vaccine dose against COVID-19 as compared to professionals with $<3$ years. This result was inconsistent with a study conducted in Greece showing that respondents with fewer work experience years were more likely to be vaccinated than participants unwilling to be vaccinated and Democratic Republic of the Congo. ${ }^{43,45}$ Older people possible being more exposed to the pandemic than the younger generation might be a possible explanation for this variation.

This study shows that subjects who were married were 2-times $(\mathrm{AOR}=2.47,95 \% \mathrm{CI}=1.33-5.95)$ more likely to have favorable attitudes towards the second vaccine dose against COVID-19 when compared to those who were not married. The study is consistent with a study conducted in China that being married made subjects more likely to have vaccine acceptance as compared to being single. ${ }^{20}$ However, as with a study conducted in the Democratic Republic of the Congo, marital status has no association towards the intention to receive second COVID-19 vaccine doses. ${ }^{43}$ When the risk degree was assessed, respondents with a high risk were 2-times more likely to have a good attitude towards second vaccine dose against COVID-19 $(\mathrm{AOR}=2.33,95 \% \mathrm{CI}=1.31-4.11)$. Another study conducted in Italy was consistent with the result. ${ }^{43}$

Gender also associated with attitude towards the second COVID-19 vaccine doses. Accordingly, being male was 3-times $(\mathrm{AOR}=3.42,95 \% \mathrm{CI}=2.91-4.98)$ more likely to have a favorable attitude towards second COVID-19 vaccine doses. This result was inconsistent with a study conducted in Bangladesh and west India. ${ }^{17,21}$ Socio-demographic culture could be the possible explanations for this variation due to gender responsibility in Ethiopia and India has variation especially in the manner of marriage. It was consistent with other studies that being male in general had a significant association towards second COVID-19 vaccine doses. $^{46,48,50}$

\section{Conclusion}

The total knowledge score of study participants' towards COVID-19 second vaccine doses was 64 , whereas $87 \%$ for attitude. The study has found significant factors that affect healthcare providers' knowledge and attitude towards second COVID-19 vaccine doses. The study found that profession, educational status, and age have a significant impact on health care professionals' knowledge towards second COVID-19 vaccine doses. It is also suggested that other factors like marital status, work experience; age, educational status, profession; risk degree and gender were the determinant factor for attitude towards second COVID-19 vaccine dose in this study. Knowledge of healthcare providers' towards second COVID-19 vaccine doses in the study setting is relatively low. This clearly implicate that the need to fill the knowledge gap in second COVID-19 vaccine doses among healthcare professionals which may help them to increase their knowledge to improve distribution of second COVID-19 vaccine doses for all targeted groups to reduce the transmission rate of the pandemic.

\section{Abbreviations}

$\mathrm{CI}$, confidence interval; $\mathrm{COR}$, crude odds ratio; AOR, adjusted odds ratio; $\mathrm{MoH}$, Ministry of Health; WHO, World Health Organization. 


\section{Data Sharing Statement}

The datasets generated and/or analyzed during the current study will be available upon request from the corresponding author.

\section{Ethics Approval and Consent to Participate}

The study protocol was reviewed and approved board of Mettu University and Informed consent was obtained from each study participant. The participants consent included publication of anonymous responses and this study was conducted in accordance with the Declaration of Helsinki.

\section{Acknowledgments}

The authors would like to thank Mettu University College of health sciences for the approval of ethical clearance.

\section{Author Contributions}

All authors contributed to data analysis, drafting or revising the article, have agreed on the journal to which the article will be submitted, gave final approval of the version to be published, and agree to be accountable for all aspects of the work.

\section{Disclosure}

The authors declare that they have no conflicts of interest in this work.

\section{References}

1. Cao X. COVID-19: immunopathology and its implications for therapy. Nat Rev Immunol. 2020;20(5):269-270. doi:10.1038/s41577-0200308-3

2. Gu J. What is coronavirus? Chin Med J (Engl). 2003;116(5):776.

3. Hogan AB, Jewell B, Sherrard-smith E. Rolling updates on coronavirus disease (COVID-19). $3^{\text {rd }}$ walk the talk: health for all challenge goes virtual; 2021.

4. Pogue K, Jensen JL, Stancil CK, et al. Influences on attitudes regarding potential covid-19 vaccination in the united states. Vaccines. 2020;8(4):1-14. doi:10.3390/vaccines 8040582

5. Fauci AS, Lane HC, Redfield RR. Covid-19 - navigating the uncharted. $N$ Engl J Med. 2020;382(13):1268-1269. doi:10.1056/ NEJMe2002387

6. Di MG, Di GP, Di GA, et al. Knowledge and attitude towards vaccination among healthcare workers: a multicenter cross-sectional study in a Southern Italian Region. Vaccines. 2020;8(2):248.

7. Lee H, Moon SJ, Ndombi GO, Kim KN, Berhe H, Nam EW. Covid-19 perception, knowledge, and preventive practice: comparison between south korea, ethiopia, and democratic republic of congo. Afr J Reprod Health. 2020;24(2Special Edition COVID-19):66-77.

8. Kebede T, Kumar D, Sharma PK. COVID-19 in Ethiopia: recommendations based on lesson learned from china. Adv Biores. 2020;(5):1114.

9. Icrc T, Red E, Society C. COVID-19 fact Sheet; 2020 May.
10. Severe I. Case management protocol for corona virus disease-19 (COVID-19) in Ethiopia. March 2020 Introduction; 2020.

11. National Disaster Risk Management Commission (NDRMC), OCHA Ethiopia. Ethiopia: COVID-19 Humanitarian impact situation update no. 01. Ocha; 2020: 1-5.

12. Biadgilign S, Yigzaw M. Covid-19 in ethiopia: current situation, missed opportunities, and the risk of health system disruptions. Pan Afr Med J. 2020;35(Supp 2):1-2. doi:10.11604/pamj. supp.2020.35.2.23906

13. Thaker J. Planning for a COVID-19 vaccination campaign: the role of social norms, trust, knowledge, and vaccine attitudes. PsyArXiv. 2012;66:37-39.

14. Zhang KC, Fang Y, Cao H, Chen H, Hu T, Chen Y. Behavioral intention to receive a COVID-19 vaccination among chinese factory workers: cross-sectional online survey corresponding author. $J$ Med Internet Res. 2021;23:1-17.

15. Popa GL, Muntean AA, Muntean MM, Popa MI. Knowledge and attitudes on vaccination in southern romanians: a cross-sectional questionnaire. Vaccines. 2020;8(4):1-7. doi:10.3390/ vaccines 8040774

16. Al-qerem WA. COVID-19 vaccination acceptance and its associated factors among a Middle Eastern population. Front Public Health. 2021;9:34.

17. Bhartiya S, Kumar N, Singh T, Murugan S, Rajavel S, Wadhwani M. Knowledge, attitude and practice towards COVID-19 vaccination acceptance in West India. Int $J$ Community Med Public Heal. 2021;8(3):1170. doi:10.18203/2394-6040.ijcmph20210481

18. Cordina M, Lauri MA, Lauri J. Attitudes towards COVID-19 vaccination, vaccine hesitancy and intention to take the vaccine. Pharm Pract (Granada). 2021;19(1):2317. doi:10.18549/ PharmPract.2021.1.2317

19. Gagneux-Brunon A, Detoc M, Bruel S, et al. Intention to get vaccinations against COVID-19 in French healthcare workers during the first pandemic wave: a cross-sectional survey. J Hosp Infect. 2021;108:168-173. doi:10.1016/j.jhin.2020.11.020

20. Wang J, Jing R, Lai X, et al. Acceptance of covid-19 vaccination during the covid-19 pandemic in china. Vaccines. 2020;8(3):1-14. doi:10.3390/vaccines 8030482

21. Bennetts LG, Dylejko P, Skvortsov A. Effective properties of acoustic metamaterial chains with low-frequency bandgaps controlled by the geometry of lightweight mass-link attachments. $J$ Sound Vibration. 2019;456:1-2.

22. Bode L, Vraga EK. In related news, that was wrong: the correction of misinformation through related stories functionality in social media. $J$ Commun. 2015;65(4):619. doi:10.1111/jcom.12166

23. Betsch C, Renkewitz F, Betsch T, Ulshofer C. The influence of vaccine-critical websites on perceiving vaccination risks. $J$ Health Psychol. 2010;15(3):446. doi:10.1177/1359105309353647

24. Issit M, McCaffrey P. Conspiracy Theories. 2012.

25. Bernhardt JM, Brownfield ED, Parker RM, Schwartzberg JG, VanGeest JB, Wang CC. Understanding Health Literacy: Implications for Medicine and Public Health. 2005:3-26.

26. Ballaro B, Goodwin C, McCaffrey P. Conspiracy Theories. 2012.

27. Abel T, McQueen DV, Kickbusch I. Health and Modernity: The Role of Theory in Health Promotion. 2007:43-73.

28. Chen L, Zhang Y, Young R, Wu X, Zhu G. Effects of vaccine-related conspiracy theories on Chinese young adults' perceptions of the HPV vaccine: an experimental study. Health Commun. 2020;1-11. doi:10.1080/10410236.2020.1751384

29. Bashirian S, Hidarnia A, Allahverdipour H, Hajizadeh E. Application of the theory of planned behavior to predict drug abuse related behaviors among adolescents. J Res Health Sci. 2012;12(1):54.

30. Barraza L, Reiss D, Freeman P. Legal and policy responses to vaccine-preventable disease outbreaks. J Law Med Ethics. 2019;47 (2_suppl):11-14. 
31. Andrews K, Silk K, Eneli I. Parents as health promoters: a theory of planned behavior perspective on the prevention of childhood obesity. J Health Commun. 2010;15(1):95. doi:10.1080/10810730903460567

32. Anderson C, Noar S, Rogers B. The persuasive power of oral health promotion messages: a theory of planned behavior approach to dental checkups among young adults. Health Commun. 2013;28(3):304. doi:10.1080/10410236.2012.684275

33. Ajzen I. The theory of planned behavior. Organ Behav Hum Decis Process. 1991;50(2):179. doi:10.1016/0749-5978(91)90020-T

34. Quinn A, Parish J, Parker M. Tout Est Lie: The Front National and Media Conspiracy Theories. 2001.

35. Offit PA. Deadly Choices: How the Anti-Vaccine Movement Threatens Us All. 2011.

36. Kalichma S. Denying AIDS: Conspiracy Theories, Pseudoscience, and Human Tragedy. 2009.

37. Cirrincione L, Plescia F, Ledda C, et al. COVID-19 pandemic: prevention and protection measures to be adopted at the workplace. Sustain. 2020;12(9):1-18. doi:10.3390/su12093603

38. Di Gennaro F, Pizzol D, Marotta C, et al. Coronavirus diseases (COVID-19) current status and future perspectives: a narrative review. Int J Environ Res Public Health. 2020;17(8):8. doi:10.3390/ ijerph17082690

39. Chen L, Zhang Y, Young R, Wu X, Zhu G. Effects of vaccine-related conspiracy theories on chinese young adults' perceptions of the hpv vaccine: an experimental study. Health Commun. 2020;1-11.

40. Krishna A. Poison or prevention? Understanding the linkages between vaccine-negative individuals' knowledge deficiency, motivations, and active communication behaviors. Health Commun. 2018;33 (9):1088-1096. doi:10.1080/10410236.2017.1331307

41. Liu R, Zhang Y, Nicholas S, Leng A, Maitland E, Wang J. COVID19 vaccination willingness among chinese adults under the free vaccination policy. Vaccines. 2021;9(3):292. doi:10.3390/ vaccines 9030292

42. Liu Z, Yang JZ. In the Wake of Scandals: how media use and social trust influence risk perception and vaccination intention among Chinese parents. Health Commun. 2020;1-12.
43. Nzaji MK, Ngombe LK, Mwamba GN, Miema JM, Lungoyo CL, Mwimba BL. Acceptability of vaccination against COVID-19 among healthcare workers in the Democratic Republic of the Congo. Pragmat Obs Res. 2020;11:103-109.

44. Shekhar R, Sheikh AB, Upadhyay S, Singh M, Kottewar S. COVID19 vaccine acceptance among health care workers in the United States. Vaccines. 2021;9:1-15.

45. Papagiannis D, Malli F, Raptis DG, et al. Assessment of knowledge, attitudes, and practices towards new coronavirus (SARS-CoV-2) of health care professionals in greece before the outbreak period. Int $J$ Environ Res Public Health. 2020;17(14):1-14. doi:10.3390/ ijerph17144925

46. Verger P, Scronias D, Dauby N, Adedzi KA, Gobert C, Bergeat M. Attitudes of healthcare workers towards COVID-19 vaccination: a survey in France and French-speaking parts of Belgium and Canada, 2020. Eurosurveillance. 2021;26(3):1-8. doi:10.2807/1560-7917. ES.2021.26.3.2002047

47. Sherman SM, Smith LE, Sim J, et al. COVID-19 vaccination intention in the UK: results from the COVID-19 vaccination acceptability study (CoVAccS), a nationally representative cross- sectional survey. Hum Vaccin Immunother. 2020;17(6):1-10.

48. Ledda C, Costantino C, Cuccia M, Maltezou HC, Rapisarda V. Attitudes of healthcare personnel towards vaccinations before and during the COVID-19 pandemic. Int J Environ Res Public Health. 2021;18(5):2703

49. National Public Health Emergency Operation Center (PHEOC), Ethiopia. COVID-19 pandemic preparedness and response in Ethiopia. Wkly Bull; 2021.

50. Paul E, Steptoe A, Fancourt D. Attitudes towards vaccines and intention to vaccinate against COVID-19: implications for public health communications. Lancet Reg Health Eur. 2021;1:100012
Infection and Drug Resistance

\section{Publish your work in this journal}

Infection and Drug Resistance is an international, peer-reviewed openaccess journal that focuses on the optimal treatment of infection (bacterial, fungal and viral) and the development and institution of preventive strategies to minimize the development and spread of resistance. The journal is specifically concerned with the epidemiology of

\section{Dovepress}

antibiotic resistance and the mechanisms of resistance development and diffusion in both hospitals and the community. The manuscript management system is completely online and includes a very quick and fair peerreview system, which is all easy to use. Visit http://www.dovepress.com/ testimonials.php to read real quotes from published authors. 